\title{
Emotional Self-Efficacy among A Sample of Faculty Members and Its Relation to Gender (Male/Female), Experience, Qualification, and Specialization
}

\author{
Samer A. Abdel-Hadi ${ }^{1}$ \\ ${ }^{1}$ Mass Communication College, Al Falah University, Dubai, UAE \\ Correspondence: Samer A. Abdel-Hadi, Mass Communication College, Al Falah University, Dubai, UAE
}

Received: September 13, 2016

Accepted: October 28, $2016 \quad$ Online Published: December 26, 2016

doi:10.5539/ies.v10n1p211

URL: http://dx.doi.org/10.5539/ies.v10n1p211

\begin{abstract}
The present study aimed to identify the level of emotional self-efficacy among a sample of faculty members who speak Arabic at the Abu Dhabi University. The study sample consisted of 99 faculty members Ph.D. and master's holders from scientific, social and education and management and humanities disciplines in University branches: Abu Dhabi and AlAin. The Arabian version of the emotional self-efficacy scale standardized on the Emirati environment was applied which consists of 27 items distributed on four aspects: using and managing your own emotions, identifying and understanding your own emotions, dealing with emotions in others and perceiving emotions through facial expressions and body language.

To detect the level of emotional self-efficacy the researcher calculated the arithmetic means, and deviations from the faculty member's performance on the four scale aspects and the scale as a whole, the results showed a high level of emotional self-efficacy with faculty members who speak Arabic at the Abu Dhabi University. The study also found that there were no statistically significant differences at the level $(0.05)$ or less between faculty members due to the variables gender (male/female), qualification, specialization, and years of experience. The researcher recommended the importance of academic community awareness of emotional self-efficacy and further studies on the subject of emotional self-efficacy in the light of other variables such as self-regulation and self-awareness.
\end{abstract}

Keywords: self-efficacy, emotional self-efficacy, emotional intelligence

\section{Introduction}

When an individual believed that he is able to gain what he wants he is more likely to succeed compared to the individual who possesses a strong low level of expectations; the ability to achieve success in a task increases the individual's desire to follow-up and track of this success. The individual gets encouragement and motivation and guidance from the beliefs he has about his abilities; he has strong expectations about achieving perfection persevere and strive; to adapt to the circumstances and believes that his abilities affect his future roles (Arghode, 2013).

The beliefs of self-efficacy: is a dynamic constructs that can be developed through the experiences of proficiency, and those beliefs influence in the amount of effort that the individual pay, the amount of perseverance to face the difficulties and susceptibility to stress and depression; they built a knowledge of high content which affect the treatment of excitement, and lead to acts in different life situations. The researchers pointed to the positive relationship between high self-efficacy beliefs and adapt versus negative relationship between the beliefs of low self-efficacy and adaptation.

The beliefs of self-efficacy does not work in isolation from each other, and therefore self-efficacy theory expanded; to determine the different beliefs of self-efficacy related to emotional self-efficacy as the emotional self-efficacy is yet one dimension from self-efficacy dimensions that are related to the perceived ability to cope with negative emotions and organize it (Valois, Zullig, \& Hunter, 2013).

The history of self-efficacy in Bandura's social learning theory (1977), the theory that renamed to the social cognitive theory in 1986. The concept of self-efficacy is considered one of the basic concepts in "Pandora" theory; it believes that self-efficacy affect both: (feeling, thinking, and behavior). As for the feeling, there is a 
correlation between low senses of self-effectively and anxiety, depression, stress and lack of assistance, such individuals have low self-esteem and become pessimistic of their achievements and their personal development. And self-efficacy affects thinking, as the strong sense of effectiveness facilitates cognitive processing and performance in different situations and circumstances, including the quality of decision-making and academic achievement. As for the behavior self-efficacy can affect in the selection of individuals for activities, and levels of self-efficacy can increase or decrease the motivation. Individuals who possess a high level of self-efficacy are dealing with difficult tasks as challenges and trying to avoid it; the individual's beliefs about self-efficacy determine the level of motivation he has and also reflect the amount of effort that he will pay, and how much time will persevere to face of obstacles (Zulkosky, 2009). "Pandora" indicates the importance of self-efficacy as a set of determinants of human motivation and emotions and actions; it acts as beliefs shape the act of cognitive, emotional and motivational processes. The high level of perceived self-efficacy is associated with higher levels of the goals set by the individual to himself, which leads to a high level of commitment to the objectives (Zulkosky, 2009).

Pandora defined self-efficacy, "as the judgment of individuals on their abilities to organize and implement the trails of required actions; to achieve specific forms of performance." Bong and Skaalvik (2003) see that the provisions of self-efficacy of self-skills and general abilities are judgments about what the individual can do in the light of the skills and abilities he possessed; and thus self-efficacy demonstrate expectations and self-perception of the adequacy (E. Skaalvik \& S. Skaalvik. 2014).

As each of Younesi, Tavakoli, Hosseini, and Hashemizadeh (2014) claimed that self-efficacy "are the beliefs of the individual about the behavior and act in order to achieve the results he want to where it predict the performance achieved in a specific domain, while Goroshit and Hen (2014) defined self-efficacy as a future belief about the standard of efficiency that is expected of an individual that he shows it in a specific position.

\section{Sources of self-efficacy}

The expectations of self-efficacy are formed from the primary sources of information referred to by Bandura as the assessment of self-efficacy, and evaluation results are closer to the levels of motivation; Individuals working better when they think they are good at the task. Bandura (1977) pointed out four main sources of information as follows:

\section{Proficiency and expertise performance}

When we succeed in the task it shows a sense of effectiveness (Zulkosky, 2009). And when we try to do something and succeed by showing our mastery of those experiences- that experiences which lead us to reach self-efficacy- because individuals are more likely to believe that they can do something new if it is same and similar to something already have done (Dagleish \& Power, 1999). Thus self-efficacy beliefs are affected by performance experiences; when we succeed in controlling a behavior, or controlling over a domain, self-efficacy is usually stronger (Mddux \& Vokmann, 2010).

\section{Indirect experiences}

The individual observe others to form expectations about their behavior and their results; observing the success of others (models) who are similiar to them and watch their succeed can drive an individual to attempt to develop self-efficacy, and the opposite happens when observing someone similar while he fails, and this detract or threat self-efficacy, taking into account the impact of indirect experiences on self-efficacy is linked to the extent of the belief of the observed person that the other person similar to him; the more that person is similar to the observant the more he will think that he can achieve the behavior that has been observed (Mddux \& Vokmann, 2010; Dagleish \& Power, 1999)

\section{Verbal persuasion}

The third factor which affects the self-efficacy is the verbal or social persuasion; when the individual is convinced that he can master a task he will be more likely to perform that task. What others are saying to us about our capabilities and the probability of success affects the beliefs of efficiency we have, taking into account the fact that the power of verbal persuasion depends on the source characteristics such as: (specialization and professionalism, confidence, and gravity) (Mddux \& Vokmann, 2010; Dagleish \& Power, 1999; Zulkosky, 2009).

\section{Physical and emotional indicators}

The physical and emotional states can affect self-efficacy; if the individual connect between poor performance or perception of failure to raise the physical uncomfortable and negative emotions in a state of anxiety it would doubt his ability, and be more likely to feel no confidence in his ability to perform effectively (Mddux \& 
Vokmann, 2010). The physical and emotional situations that arise when the individual did a behavior, or even when he imagine doing this behavior affect self-efficacy and can lead to fulfilling prophecy that achieve itself, indicators such as: (anxiety, tension, and fear have negative impact on self-efficacy and can lead to failure or inability to perform the task (Mddux \& Vokmann, 2010; Dagleish \& Power, 1999; Zulkosky, 2009).

\subsection{The Problem of the Study}

The confidence of a faculty member in his ability to influence the students' learning and his beliefs in self-efficacy are but provisions for his abilities in influencing desirable outcomes related to student performance, and behavior, and motivation within the classroom. And the level of self-efficacy among faculty members is linked to job satisfaction, job stress, profession burnout and teaching practice, and enthusiasm, and behavior inside the classroom, and the teacher's self-efficacy is linked to outputs such as :( student's beliefs about self-efficacy, and involvement, participation, motivation, and achievement) (Goroshit \& Hen, 2014).

Brigido, Borrachero, Bermejo, and Mellado (2013), Gibson and Dembo (1984) pointed out that the faculty members who possess a high level of self-efficacy are less critical of their students in a way they are more perseverance in the attitudes of failure and repetition in addition to the link to the effectiveness of faculty members to increase the academic achievement of the students and the positive trends towards teaching. While low self-efficacy among faculty members is associated with the internal professional burn out, and the increase of the level of anxiety and various forms of negative behaviors. Emotional self-efficacy among faculty members Require the awareness of self-emotions and the ability to regulate these emotions to achieve the desired results. The beliefs of self-efficacy affect the responses of emotional acts; the faculty member through self-regulation of emotions process collect information and feedback about the progress of the target, and who owns strong beliefs about the effectiveness of emotions less likely to fail in the self-regulation and is working to increase positive emotions; those emotions that expand thought processes and increase flexibility, creativity, and problem solving efficiently and development of skills over time (Maddux \& Vokmann, 2010).

Thus emotional self-efficacy plays a dual role among the faculty members where it helps him on the integration and compatibility with social and emotional system, and this is a prelude to achieve professional success, while self-efficacy helps faculty members on the upbringing of their students by helping in the development of high levels of social and emotional adequacy (Goroshit \& Hen, 2014; E. Skaalvik \& S. Skaalvik, 2007).

\subsection{Questions of the Study}

The current study tried to answer the following questions:

1) What is the level of emotional self-efficacy among a sample of faculty members who speak Arabic at Abu Dhabi University?

2) Are there any statistically significant differences at the level of significance $(0.05)$ or less in the level of emotional self-efficacy among a sample of faculty members due to the variables: gender, years of experience, qualification, and specialization?

\subsection{The Significance of the Study}

This study derives its importance from the nature of the subject matter it tackled; the faculty member seeks to build effective relationships with students and co-workers, and needs personal beliefs about his self-efficacy in managing and organizing and controlling the emotions so that he can achieve the objectives sought to be achieved. The current study reveals the emotional self-efficacy among a sample of faculty members which contribute to the enrichment of the theoretical literature effectively, and to provide the Arabic library with theoretical information on this topic.

The results of this study will provide interested educators with information that may help in the movement towards the construction and preparation of training and extension programs and scientific meetings; to assist faculty members in universities and teachers in improving the level of emotional self-efficacy they have.

\subsection{Study Limitations}

The results of this study are determined by:

- Sample characteristics: the faculty members at the University Abu Dhabi who are speaking Arabic.

- The psychometric properties of the study tool which is prepared for the purposes of the present study, The Emotional Self-Efficacy Scale.

\subsection{Definition of Terms}

Emotional Self-Efficacy: It means: individual beliefs and provisions towards his abilities to distinguish 
emotional situation, and to understand the feelings of others, and to identify positive and negative emotional expressions with a level of self-confidence of an ability to adapt to emotional effectively situation and adapt to the surrounding events, and the ability perceived as avoiding anger and frustration and negative emotions and face success and positive events and the expression of positive emotions in an appropriate manner (Zhao et al., 2013). And it is an individual's judgment on his ability to identify and understand self-emotions and manage those emotions, and dealing with the emotions that emerge from the others, and the ability to perceive emotion through facial expressions and body language, which is calculated by the degree which the faculty member obtain on emotional self-efficacy scale used for the purposes of this study.

\section{Literature Review}

Research of emotional intelligence at the beginning of (1990) contributes in understanding how individuals differ in their emotional operations, and how these differences affect their social function. Studies have shown the effectiveness of the self that what the individual does is integrated between the product of cognitive, social and emotional skills. And that the individual is capable of doing what he realizes that he will be able to do, and these beliefs are the mediator between capacity and act. And emotional intelligence is the ability, but it is a weak prompt of the performance of the individual, and the emotional self-efficacy facilitate this role, which mediates the ability of the individual and emotional performance, and it can be a practical outputs of the ability of emotional intelligence (Choi, Kluemper, \& Sauley, 2013); the individual may possess the ability to read emotions well among others, or self-emotions management, but he may decide not to use any of these capabilities, and the probability could be because he does not have the motivation to do so, or because of a lack of self-efficacy in this field; Individuals who believe that they have some control and control emotions are more successful in regulating their emotions than those who think that this thing cannot be controlled effectively (Pool \& Qualter, 2013).

The emotional self-efficacy in the psychological and educational literature is seen as a base for the ability of emotional intelligence. And self-efficacy does not include regulate emotions and only, but it includes other elements and dimensions, such as: (recognize and understand emotions, and beliefs of the individual about his emotional abilities). emotional self-efficacy differs from the feature of emotional intelligence, despite the fact that some research indicated that emotional intelligence feature is a constant tendency can be considered or relevant to as self-efficacy or self-concept in emotions, but the emotional self-efficacy reflect the beliefs of the individual of his emotional and dynamic abilities, that are evolving and growing through experiences (Choi, Kluemper, \& Sauley, 2013).

Goroshit and Hen (2014) stated that emotional self-efficacy "is the individual governing of his ability in processing emotional information properly and effectively; it is the power variable that affects the emotional state of an individual and in his performance." The term of emotional self-efficacy combines between the concept of self-efficacy in the theory of the scientist "Pandora" and the theory of emotional intelligence; Individuals realize themselves that they have a good balance between emotion and ideas; where the ability to organize self-emotions and other emotions, the thoughts and beliefs in order to provide easy to use input for the act.

Dogan, Tatan, and Sapmaz (2013), Valois, Zullig, and Hunter (2013) see that the concept of emotional self-efficacy associated with the effective use of individual emotions and emotional self-efficacy is multidimensional concept consists of self-regulation of emotions, and self-understanding of emotions and the emotions of others, and recognize the emotions and used it to support the thinking.

Valois, Zullig, and Hunter (2013) in their study examined the relationship between the perception of suicide and attempt to suicide behavior and emotional self-efficacy among a sample of graduate school students in the schools of the classes (9-12) age (12-18 years) in Carolina. The study suggests that the lower levels of emotional self-efficacy can be associated in a meaningful way with the highest levels in the perception of suicide and suicide attempts for the participants in the study. The researchers added a part of emotional self-efficacy scale in a questionnaire (CDC) for risk behavior among young people to examine the link between the perception of suicide and suicide attempts. Then apply the adjusted and unadjusted regression analysis, models of multiple variables of gender, and race. All suicide variables were associated significantly to emotional self-efficacy in unadjusted models for groups of gender and race, and the suicide attempt that resulted embarrassment associated with low emotional self-efficacy among black females and white males. Depicting suicide, suicide attempt that resulted embarrassment associated with the low level of self-efficacy.

Dacre and Qualter (2013) conducted a study aimed to examine the link between jobs chances (the ability to get a job) and job satisfaction of graduates' employees. The study sample fill emotional self-efficacy scales, and 
employability perceived self-Metrics (skills and understanding and perception), and personality traits. The study sample consisted of 306 graduates from the years 2006, 2007, 2008 who were contacted via e-mail to fill the scales of alumni club at the University at the North West of England from various disciplines such as business administration, electrical engineering, history and human resources administrative management Studies the average of their age (28 years). The researchers analyzed the data using Structural Equation Modeling. The results showed that emotional self-efficacy predicts viability graduates for employment, and the possibility of hiring mediates the relationship between emotional self-efficacy and job satisfaction. As the results show that the self-emotional efficacy in associated with the possibility of employment, as the graduates who have a high level of emotional self-efficacy also realize themselves that they are ready to hire or eligible; this means that beliefs about emotional adequacy affect in readiness (probability of employment) self-perceived; Individuals who have greater confidence in their ability to perceive, use, understand and manage emotion consider themselves more likely (probability) for recruitment.

As well as the study of Dogan, Totan, and Sapmaz (2013) which aims to examine the effect of self-esteem, and social well-being, and emotional self-efficacy in happiness? The study sample included 340 students from Turkish universities 213 females and 109 males. The researchers used the Oxford happiness questionnaire, and the measure of self-sufficiency, and the measure of emotional self-efficacy, and the measure of positive / negative events. The results showed a positive relationship with a statistically significance between the psychological well-being and self-esteem and happiness, as the positive impact of psychological well-being and happiness in the self-assessment appears. The study results also to the influence of positive emotional self-efficacy in self-esteem. And $46 \%$ of the interpreter variation in self-esteem due to the psychological and emotional well-being and emotional self-efficacy; also it explains the psychological and emotional well-being and emotional self-efficacy and self-esteem $51 \%$ of the variation of happiness.

Goroshit and Hen (2014) conducted a study aimed to investigate the predictive ability of self-efficacy of emotions in the self-efficacy of teaching, and emotional representation among a sample of teachers. The study sample consisted of 273 teachers from 10 schools; $67 \%$ were female and $33 \%$ male average age (36 years). $28 \%$ have a bachelor's degree, and $21 \%$ have master's degrees, and the rest $42 \%$ have the degree of Bachelor of Education, the average experience (12 years).

The researchers apply emotional assimilation scale, and emotional self-efficacy scale, and self-efficacy for teaching scale. The results showed that the effectiveness of self-efficacy of emotions predict both the emotional assimilation and self-efficacy for teaching among teachers; "Pearson correlation" between the variables showed that all study variables linked internally with a positive connotation. The strength of link between these variables ranged between 0.38 and 0.56 . This suggests that teachers who have demonstrated high levels of emotional self-efficacy have higher levels of emotional assimilation and self-efficacy. The results show no significant correlation between the gender: (Male / Female), academic degree with the variables of the study, while years of teaching experience have a weak positive correlation with the changes.

\section{Study Design and Methodology}

The researcher depend in this study on descriptive approach, for its suitability for the purposes of the present study; the study aimed to identify the level of emotional self-efficacy among a sample of faculty members at Abu Dhabi University (Abu Dhabi and Al Ain Branch) who speak the Arabic language, and the extent of the difference in emotional self-efficacy of due to gender: (Male / Female), years of experience, academic qualification, and specialization.

\subsection{The Population of the Study and Its Sample}

The study population consisted of all faculty members who speak Arabic at the University of Abu Dhabi (Abu Dhabi and Al Ain Branch) totaling (128), according to statistics of the human resources department at Abu Dhabi University in the first semester of the academic year (2015/2016). The study sample included 99 members of the faculty. The emotional self-efficacy scale has been distributed and sent via email. Table No. 1 shows the frequencies and percentages for the study sample according to gender: (male/female), years of experience, academic qualification and specialization. 
Table 1. Frequencies and percentages according to the study variables

\begin{tabular}{llcc}
\hline Variable & Categories & Frequency & Percentage \\
\hline \multirow{2}{*}{ Gender } & Male & 80 & 80.8 \\
\cline { 2 - 4 } & Female & 19 & 19.2 \\
\hline \multirow{4}{*}{ Experience } & Less than 5 years & 20 & 20.2 \\
\cline { 2 - 4 } & From 5-9 years & 28 & 28.3 \\
\cline { 2 - 4 } & From 10-14 years & 24 & 24.2 \\
\cline { 2 - 4 } & 15 years or above & 27 & 27.3 \\
\hline \multirow{2}{*}{ Scientific qualification } & Master & 21 & 21.2 \\
\cline { 2 - 4 } & PhD & 78 & 78.8 \\
\hline \multirow{3}{*}{ Specialization } & Scientific disciplines & 40 & 40.4 \\
\cline { 2 - 4 } & Social displines and Education & 8 & 8.1 \\
\cline { 2 - 4 } & Administration and Humanities & 51 & 51.5 \\
\hline Total & & 99 & 100.0 \\
\hline
\end{tabular}

\subsection{The Study Tool}

The author developed the Emotional Self-Efficacy Scale (Pool \& Qualter, 2012) where he translated the scale and presented in its two Arabic and English versions to two Professors one is specialized in English language and the other in Arabic language. The formula of some items was amended; to fit the notes of the two arbitrators. The number of items of the scale in its original form was 27 items, representing a description of the effectiveness of the self- emotions; and the items are distributed on four domains:

- $\quad$ Using and managing your own emotions, it includes the items $(3,5,7,10,12,15,16,19,23,25)$

- Identifying and understanding your own, it includes the items $(1,4,8,9,17,24)$

- Dealing with emotions in others, it includes the items $(2,6,11,13,20,21,26,27)$

- Perceiving emotions through facial expressions and body language, it includes the items $(14,18,22)$

\subsubsection{Validity of the Tool}

Internal construction: it has been confirmed that there is a correlation between each domain of the scale with a total score; in order to verify the validity of the internal construction. There was a correlation between all domains on one hand and the total score on the other hand, Tables 2 and 3 show the matrix of correlation coefficients between the domains of the scale, and between the domains of the scale and the total score:

Table 2 . The results of the internal construction validity

\begin{tabular}{|c|c|c|c|c|c|c|c|c|}
\hline $\begin{array}{l}\text { Item } \\
\text { No. }\end{array}$ & $\begin{array}{c}\text { The } \\
\text { correlation } \\
\text { coefficient } \\
\text { With } \\
\text { Domain }\end{array}$ & $\begin{array}{l}\text { The } \\
\text { correlation } \\
\text { Weitbffheidobl }\end{array}$ & $\begin{array}{l}\text { Item } \\
\text { No. }\end{array}$ & $\begin{array}{l}\text { The } \\
\text { correlation } \\
\text { coefficient } \\
\text { With Domain }\end{array}$ & $\begin{array}{c}\text { The } \\
\text { correlation } \\
\text { Weitbffheienol }\end{array}$ & $\begin{array}{l}\text { Item } \\
\text { No. }\end{array}$ & $\begin{array}{l}\text { The } \\
\text { correlation } \\
\text { coefficient } \\
\text { With Domain }\end{array}$ & $\begin{array}{c}\text { The correlation } \\
\text { coefficient } \\
\text { With the tool }\end{array}$ \\
\hline 1 & $.58 * *$ & $.53 * *$ & 10 & $.37^{*}$ & $.48 * *$ & 19 & $.58 * *$ & $.48^{* *}$ \\
\hline 2 & $.68^{* *}$ & $.63 * *$ & 11 & $.53^{* *}$ & $.51^{* *}$ & 20 & $.49 * *$ & $.49 * *$ \\
\hline 3 & $.67^{* *}$ & $.56^{* *}$ & 12 & $.63 * *$ & $.50 * *$ & 21 & $.64^{* *}$ & $.61^{* *}$ \\
\hline 4 & $.55^{* *}$ & $.37^{*}$ & 13 & $.54 * *$ & $.39 *$ & 22 & $.76^{* *}$ & $.61^{* *}$ \\
\hline 5 & $.79 * *$ & $.67 * *$ & 14 & $.80 * *$ & $.60 * *$ & 23 & $.43 *$ & $.58 * *$ \\
\hline 6 & $.46^{* *}$ & $.44^{*}$ & 15 & $.72 * *$ & $.64 * *$ & 24 & $.51 * *$ & $.66^{* *}$ \\
\hline 7 & $.80^{* *}$ & $.70 * *$ & 16 & $.46^{* *}$ & $.50 * *$ & 25 & $.54 * *$ & $.67 * *$ \\
\hline 8 & $.73^{* *}$ & $.49 * *$ & 17 & $.61^{* *}$ & $.49 * *$ & 26 & $.75^{* *}$ & $.60 * *$ \\
\hline 9 & $.36^{*}$ & $.41 *$ & 18 & $.58 * *$ & $.48 * *$ & 27 & $.57 * *$ & $.47 * *$ \\
\hline
\end{tabular}

\footnotetext{
* Statistically significant at the significance level (0.05).
}

** Statistically significant at the significance level $(0.01)$. 
Table 3. Correlation coefficients between dimensions and the total score

\begin{tabular}{|c|c|c|c|c|c|}
\hline Dimensions & $\begin{array}{l}\text { Use and } \\
\text { management of } \\
\text { self-emotions }\end{array}$ & $\begin{array}{l}\text { Identify and } \\
\text { understand } \\
\text { self-emotions }\end{array}$ & $\begin{array}{l}\text { Dealing with the } \\
\text { emotions of } \\
\text { others }\end{array}$ & $\begin{array}{c}\text { Perception of emotion } \\
\text { through facial expressions } \\
\text { and body language }\end{array}$ & $\begin{array}{l}\text { Total } \\
\text { degree }\end{array}$ \\
\hline $\begin{array}{l}\text { use and management of self- } \\
\text { emotions }\end{array}$ & 1 & & & & \\
\hline $\begin{array}{l}\text { Identify and understand self- } \\
\text { emotions }\end{array}$ & $.637 * *$ & 1 & & & \\
\hline $\begin{array}{l}\text { Dealing with the emotions of } \\
\text { others }\end{array}$ & $.618 * *$ & $.475 * *$ & 1 & & \\
\hline $\begin{array}{l}\text { Perception of emotion } \\
\text { through facial expressions } \\
\text { and body language }\end{array}$ & $.732 * *$ & $.483 * *$ & $.673 * *$ & 1 & \\
\hline Total degree & $.937 * *$ & $.741 * *$ & $.819^{* *}$ & $.790 * *$ & 1 \\
\hline
\end{tabular}

*Statistically significant at the significance level $(0.05)$.

** Statistically significant at the significance level $(0.01)$.

It is noted from Tables 2 and 3 that the correlation coefficients between the domains of the scale and the grade ranged between $(0.37-0.70)$, and with the domain $(0.36-0.80)$. All of these transactions are significant at the level of $(0.05)$ or less, and this indicates that the scale has appropriate validity connotations, and meets the objectives of the current study; therefore, none of these items were deleted.

Arbitrators' validity: the tool was presented to 6 arbitrators who are specialists in the field of counseling and mental health and educational psychology in Amman Private University, the University of Abu Dhabi, and each arbitrator was asked to express his opinion on the clarity of the items, and its measuring of the concept it was prepared to, and how it is related to the sub-scale and the wording of some items was amended; to fit the arbitrators' notes.

\subsubsection{Reliability}

To verify the reliability of the scale; the reliability of the internal consistency coefficient was calculated using Cronbach's alpha equation on a pilot sample from outside the study sample and totaling 32; and in order to calculate the ability of the items of the scale on discrimination based on association with the total degree. And Table 4 shows such transactions, and these ratios were considered appropriate for the purposes of this study.

Table 4. Internal consistency coefficient Cronbach's alpha

\begin{tabular}{lc}
\hline Dimensions & Internal consistency \\
\hline use and management of self- emotions & 0.80 \\
Identify and understand self- emotions & 0.70 \\
Dealing with the emotions of others & 0.72 \\
Perception of emotion through facial expressions and body language & 0.71 \\
Total degree & 0.88 \\
\hline
\end{tabular}

\section{Results of the Study and Its Discussion}

The first Question: What is the level of emotional self-efficacy among a sample of faculty members who speak Arabic at Abu Dhabi University?

To answer this question, the arithmetic means and standard deviations for the performance of faculty members on the domains of emotional self-efficacy scale were calculated, and each level of the domain was calculated. It was based on the following calculations in determining the length of each category of self-emotional efficacy (high, medium, and low) for each of the four domains of the scale: (upper limit of the calibrato-minimum used gradation/ number of degree of commonality levels), and thus be $(4-0) / 3=1.33$, which represents the length of one category, and then collected the minimum scale, and thus the degree of prevalence of emotional self-efficacy among faculty members based on the arithmetic mean is:

- $\quad$ Less than 1.33 low. 
- $\quad$ From 1.34-2.67 medium.

- $\quad 2.68$ And more high.

Table 5 shows the level of emotional self-efficacy among a sample of the faculty members at Abu Dhabi University.

Table 5. Means and standard deviations for the level of emotional self-efficacy among faculty members in descending order according to means

\begin{tabular}{|c|c|c|c|c|c|}
\hline Rank & No. & Dimension & Mean & $\begin{array}{l}\text { Standard } \\
\text { deviation }\end{array}$ & Level \\
\hline 1 & 2 & Identify and understand self- emotions & 2.92 & .478 & High \\
\hline 2 & 4 & $\begin{array}{l}\text { Perception of emotion through facial } \\
\text { expressions and body language }\end{array}$ & 2.90 & .588 & High \\
\hline 3 & 1 & use and management of self- emotions & 2.77 & .513 & High \\
\hline 4 & 3 & Dealing with the emotions of others & 2.54 & .436 & Moderate \\
\hline \multicolumn{3}{|c|}{ Total degree } & 2.75 & 4.00 & High \\
\hline
\end{tabular}

As shown in Table 5 that the arithmetic mean of the four domains ranged between 2.54 and 2.92; The domain: (identifying and understanding the self-emotions) came in the first rank with the highest arithmetic mean 2.92, while the domain (dealing with the emotions of others) ranked last and reached a mean 2.54 , and the arithmetic mean of the instrument as a whole reached 2.75. The researcher believes that the appearance of high level of emotional self-efficacy among a sample of faculty members in the current study may be due to the experience of the sample members, the number of years they spent in the teaching profession, the newly acquired knowledge, the attitudes and concepts and beliefs they gain about the management of negative emotions and express for positive emotions in daily situations, and the ability they have to determine the emotional state and understanding of the feelings of others, and self-confidence in the ability to adapt to the emotional situation effectively (Zhao et al., 2013). Based on the opinion of each of Goroshit and Hen (2014), there are a number of internal and external variables that affect the self-emotional effectiveness; and the external variables include environmental factors: (number of students), and the tools of teaching: (teaching material), and physical conditions. The internal variables include the beliefs of the faculty member and the perception that he has the ability to control and regulate emotions and express them in an appropriate manner. It can be noted here that the beliefs of the faculty members about control and regulate emotions and their ability to organize the various shares of emotional states in possession of an average level of self-emotional effectiveness, as it and the presence of certain factors such as: (dealing with the appropriate number of students while teaching, and provide physical conditions, and teaching appropriate material) helped in the formation of the medium emotional effectiveness among a sample of faculty members in Abu Dhabi University. If taking into account the sources of the effectiveness of self-efficacy the experiences of faculty members and professional colleagues and noting their success in adjusting emotions in addition to verbal support from the surrounding environment that they are fluent in adjusting and organization agitation. All these dimensions have contributed to the formation of the ability of respondents to understand the emotions of others and self-emotions and understand the emotions and use emotions to support ideas (Dogan \& Totan, 2013; Dagleish \& Power, 1999).

However, the educational, social and cultural context may not contribute to the skill of dealing with the emotions of others is high level of development, during the stages of study and work may not be exposed to a faculty member to specialized training programs to develop that skill, and the focus is limited on academic subjects and academic achievement.

Here is a display for all arithmetic means and standard deviations of the paragraphs of each domain separately.

The First Domain: the use and management of self-emotions

The arithmetic means and standard deviations for all the paragraphs of the use and management of self-emotions were calculated. And Table 6 shows that. 
Table 6. Means and standard deviations for all the items that measure the level of use and management of selfemotions among faculty members

\begin{tabular}{llllcc}
\hline Rank & No. & Items & Mean & $\begin{array}{c}\text { Standard } \\
\text { deviation }\end{array}$ & Level \\
\hline 1 & 15 & When my emotions are positive; it helps me generate new ideas & 3.35 & .690 & High \\
2 & 5 & I focus on the positive emotions to create solutions to the problems I face & 2.95 & .962 & High \\
3 & 16 & I know the reasons for the cases of emotional change & 2.90 & .598 & High \\
4 & 10 & I adjust my emotions when I am under pressure & 2.86 & .833 & High \\
5 & 3 & When my emotions are negative, I try hard to focus on other positive emotions & 2.85 & .908 & High \\
6 & 25 & I can focus on the right emotion that leads to finding ideas & 2.79 & .860 & High \\
7 & 12 & I live the mood that suits the situation & 2.71 & .836 & High \\
8 & 19 & I focus on my emotions to develop my cognitive performance (thinking, & 2.49 & .838 & Moderate \\
9 & 7 & I remembering ...) & 2.39 & .977 & Moderate \\
10 & 23 & I focus on the emotions of the development of my physical performance & 2.39 & .890 & Moderate \\
\multicolumn{7}{l}{ Use and manage self- emotions } & 2.77 & .513 & High \\
\hline
\end{tabular}

It is noted from Table 6 that the means ranged between 2.39 and 3.35, and paragraph 15 "When my emotions are positive; it helps me to generate good ideas" came in the first place with a mean 3.35, while paragraphs 7, 23, "I can I change my negative emotion with another positive one" and "I focus on the emotions of the development of my physical performance (movement, activity...)" came last with a mean 2.39. The arithmetic mean of the domain as a whole reached 2.77 .

The Second Domain: the identification and understanding of self-emotions

The arithmetic means and standard deviations for all paragraphs of this domain were calculated. And Table 7 illustrates this:

Table 7. Means and standard deviations for all the items that measure the level of identification and understanding of self-emotions among faculty members

\begin{tabular}{|c|c|c|c|c|c|}
\hline Rank & No. & Items & Mean & $\begin{array}{l}\text { Standard } \\
\text { deviation }\end{array}$ & Level \\
\hline 1 & 8 & I Refine my positive emotions correctly & 3.17 & .590 & High \\
\hline 2 & 4 & I know the reason for feeling emotionally positive (happiness ...) & 3.15 & .800 & High \\
\hline 3 & 9 & $\begin{array}{l}\text { I know the reason for my feeling emotionally negative (sadness, } \\
\text { anger ...) }\end{array}$ & 3.09 & .784 & High \\
\hline 4 & 1 & I set properly my negative emotions & 3.01 & .721 & High \\
\hline 5 & 17 & I can calm myself when I get angry & 2.60 & .832 & Moderate \\
\hline 6 & 24 & I know the reason for feeling in a certain way & 2.53 & .761 & Moderate \\
\hline \multicolumn{3}{|c|}{ Identify and understand self- emotions } & 2.92 & .478 & High \\
\hline
\end{tabular}

The results in Table 7 Indicates that the means ranged between 2.53 and 3.17; and that the highest arithmetic mean is for paragraph No. 8 "I Refine my positive emotions correctly" where its mean reached 3.17, while the lowest arithmetic mean is for paragraph No. 24, "I know the reason for feeling in a certain way" with a mean of 2.53. The arithmetic mean of the domain as a whole reached 2.92.

The Third Domain: dealing with the emotions of others

The arithmetic means and standard deviations for all paragraphs of this domain were calculated. And Table 8 illustrates this: 
Table 8. Means and standard deviations for all the items that measure the level of dealing with the emotions of others among faculty members

\begin{tabular}{|c|c|c|c|c|c|}
\hline Rank & N. & Items & Mean & $\begin{array}{l}\text { Standard } \\
\text { deviation }\end{array}$ & Level \\
\hline 1 & 11 & $\begin{array}{l}\text { I identify, in a correct way, when others feel a positive } \\
\text { emotion }\end{array}$ & 2.89 & .819 & High \\
\hline 2 & 6 & $\begin{array}{l}\text { I can find out what may cause positive emotions to the } \\
\text { others }\end{array}$ & 2.63 & .864 & Moderate \\
\hline 3 & 27 & $\begin{array}{l}\text { I help the other person to regulate his emotions when he } \\
\text { is suffering from the loss of a loved one }\end{array}$ & 2.58 & .870 & Moderate \\
\hline 4 & 13 & $\begin{array}{l}\text { I understand what causes a sense of negative emotions to } \\
\text { others }\end{array}$ & 2.56 & .688 & Moderate \\
\hline 5 & 2 & $\begin{array}{l}\text { I help others to change negative emotions into positive } \\
\text { ones }\end{array}$ & 2.53 & .705 & Moderate \\
\hline 6 & 21 & I help others to calm themselves when they are angry & 2.42 & .716 & Moderate \\
\hline 7 & 26 & $\begin{array}{l}\text { I can find out what may cause different emotions to } \\
\text { others }\end{array}$ & 2.37 & .648 & Moderate \\
\hline 8 & 20 & $\begin{array}{l}\text { I know the reasons for changing the emotional state of } \\
\text { others }\end{array}$ & 2.31 & .633 & Moderate \\
\hline \multicolumn{3}{|c|}{ Dealing with the emotions of others } & 2.54 & .436 & Moderate \\
\hline
\end{tabular}

As shown in Table 8 that the arithmetic mean of the paragraphs of the domain "dealing with the emotions of others" ranged between (2.31-2.89), and the highest arithmetic mean is for paragraph number (11) "I identify, in a correct way, when others feel a positive emotion" with a mean (2.89), as can be seen from the table also the lowest arithmetic mean is for paragraph number (20) "I know the reasons for changing the emotional state of others" with a mean (2.31). The arithmetic mean of the domain as a whole reached (2.54).

The Fourth Domain: the level of awareness of emotion through facial expressions and body language

The arithmetic means and standard deviations for all paragraphs of this domain were calculated. Table No (9) illustrates this:

Table 9. Means and standard deviations for all the items that measure the level of awareness of emotion through facial expressions and body language among faculty members

\begin{tabular}{|c|c|c|c|c|c|}
\hline Rank & $\mathrm{N}$. & Items & Mean & $\begin{array}{l}\text { Standard } \\
\text { deviation }\end{array}$ & Level \\
\hline 1 & 14 & $\begin{array}{l}\text { I know the emotion indicated by the expressions of my } \\
\text { body (body language) }\end{array}$ & 2.99 & .614 & High \\
\hline 2 & 18 & $\begin{array}{l}\text { I discover the emotion of others through what appears } \\
\text { from their body language }\end{array}$ & 2.96 & .727 & High \\
\hline 3 & 22 & $\begin{array}{l}\text { I know what emotions I feel through my facial } \\
\text { expressions }\end{array}$ & 2.74 & .852 & High \\
\hline \multicolumn{3}{|c|}{ I realize the emotion through facial expressions and body language } & 2.90 & .588 & High \\
\hline
\end{tabular}

It is clear from Table 9 that the arithmetic mean of the paragraphs of thedomain: (perception of emotion through facial expressions and body language) ranged between (2.74-2.99), and the highest arithmetic mean is the paragraph number (14) "I know the emotion indicated by the expressions of my body (body language), "which arithmetic mean was (2.99). While the lowest arithmetic mean is the paragraph number (22) "I know what emotions I feel through facial expressions," which arithmetic mean was (2.74). The arithmetic mean of the domain as a whole reached (2.90).

The Second question: Are there any statistically significant differences at the level of significance $(0.05)$ or less in the level of emotional self-efficacy among a sample of faculty members due to the variables: gender, years of experience, qualification, and specialization?

To answer this question arithmetic means and standard deviations of the level of emotional self-efficacy among faculty members were extracted depending on the variables (gender: male/female, years of experience, 
educational qualification, and specialization), and Table 10 illustrates the results of arithmetic means and standard deviations.

Table 10. Means and standard deviations for the domains of the scale depending on the variables of (gender, years of experience, academic qualification and specialization)

\begin{tabular}{|c|c|c|c|c|c|c|c|}
\hline \multicolumn{2}{|c|}{ Variables } & \multicolumn{2}{|c|}{$\begin{array}{c}\text { Mean and standard } \\
\text { deviation }\end{array}$} & \multirow[t]{2}{*}{$\begin{array}{c}\text { usage and } \\
\text { management of } \\
\text { self-emotions } \\
2.88 \\
\end{array}$} & \multirow[t]{2}{*}{$\begin{array}{c}\begin{array}{c}\text { Identify and } \\
\text { understand } \\
\text { self-emotions }\end{array} \\
2.56 \\
\end{array}$} & \multirow[t]{2}{*}{ 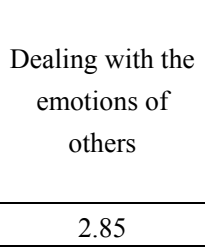 } & \multirow[t]{2}{*}{$\begin{array}{c}\text { Realize the } \\
\text { emotion through } \\
\text { facial expressions } \\
\text { and body } \\
\text { language } \\
2.74\end{array}$} \\
\hline \multirow{4}{*}{ Gender } & Male & Mean & 2.77 & & & & \\
\hline & Male & $\begin{array}{l}\text { Standard } \\
\text { deviation }\end{array}$ & .493 & .469 & .377 & .514 & .379 \\
\hline & \multirow[b]{2}{*}{ Female } & Mean & 2.75 & 3.11 & 2.45 & 3.09 & 2.78 \\
\hline & & $\begin{array}{l}\text { Standard } \\
\text { deviation }\end{array}$ & .604 & .488 & .632 & .823 & .489 \\
\hline \multirow{8}{*}{ Experience } & \multirow{2}{*}{$\begin{array}{l}\text { Less than } 5 \\
\text { years }\end{array}$} & Mean & 2.85 & 2.79 & 2.54 & 2.95 & 2.76 \\
\hline & & $\begin{array}{l}\text { Standard } \\
\text { deviation }\end{array}$ & .402 & .543 & .330 & .292 & .353 \\
\hline & \multirow[b]{2}{*}{ 5-9 years } & Mean & 2.81 & 3.01 & 2.62 & 3.04 & 2.83 \\
\hline & & $\begin{array}{l}\text { Standard } \\
\text { deviation }\end{array}$ & .457 & .366 & .373 & .562 & .361 \\
\hline & \multirow[b]{2}{*}{$10-14$ years } & Mean & 2.80 & 2.85 & 2.58 & 2.90 & 2.76 \\
\hline & & $\begin{array}{l}\text { Standard } \\
\text { deviation }\end{array}$ & .586 & .618 & .498 & .745 & .465 \\
\hline & \multirow{2}{*}{$\begin{array}{l}15 \text { years and } \\
\text { above }\end{array}$} & Mean & 2.63 & 2.99 & 2.40 & 2.70 & 2.65 \\
\hline & & $\begin{array}{l}\text { Standard } \\
\text { deviation }\end{array}$ & .568 & .371 & .493 & .602 & .410 \\
\hline \multirow{4}{*}{$\begin{array}{c}\text { Academic } \\
\text { qualification }\end{array}$} & Master degree & Mean & 2.87 & 2.75 & 2.62 & 2.86 & 2.77 \\
\hline & & $\begin{array}{l}\text { Standard } \\
\text { deviation }\end{array}$ & .453 & .482 & .443 & .793 & .422 \\
\hline & \multirow[b]{2}{*}{$\mathrm{PhD}$} & Mean & 2.74 & 2.97 & 2.51 & 2.91 & 2.74 \\
\hline & & $\begin{array}{l}\text { Standard } \\
\text { deviation }\end{array}$ & .527 & .470 & .434 & .526 & .396 \\
\hline \multirow{6}{*}{ Specialization } & \multirow{2}{*}{$\begin{array}{c}\text { Scientific } \\
\text { specialization }\end{array}$} & Mean & 2.74 & 2.84 & 2.54 & 2.88 & 2.72 \\
\hline & & $\begin{array}{l}\text { Standard } \\
\text { deviation }\end{array}$ & .431 & .357 & .382 & .463 & .321 \\
\hline & \multirow{2}{*}{$\begin{array}{c}\text { Social } \\
\text { and } \\
\text { educational } \\
\text { majors } \\
\end{array}$} & Mean & 2.85 & 3.08 & 2.53 & 2.50 & 2.77 \\
\hline & & $\begin{array}{l}\text { Standard } \\
\text { deviation }\end{array}$ & .616 & .367 & .416 & .777 & .494 \\
\hline & \multirow{2}{*}{$\begin{array}{c}\text { Administration } \\
\text { and Human } \\
\text { Sciences }\end{array}$} & Mean & 2.78 & 2.97 & 2.53 & 2.97 & 2.77 \\
\hline & & $\begin{array}{l}\text { Standard } \\
\text { deviation }\end{array}$ & .561 & .564 & .484 & .628 & .445 \\
\hline
\end{tabular}

It is noted from Table 10 that there are apparent differences between the means in sub-domains: (usage and management of self-emotions, and, identify and understand the self-emotions, and, dealing with the emotions of others, and understand emotion through facial expressions and body language, and the scale as a whole), depending on the variables of gender and years of experience and academic qualification and specialization. In order to verify the significance of differences; analysis of quadruple variance (ANOVA) was conducted, and Table 11 shows the results of this analysis. 
Table 11. Results of analysis of quadruple variance (ANOVA) of all the domains of the scale depending on the variables: (gender, years of experience, academic qualification and specialization)

\begin{tabular}{|c|c|c|c|c|c|c|}
\hline Source of variance & Domains & $\begin{array}{l}\text { Sum of } \\
\text { squares }\end{array}$ & Df & $\begin{array}{l}\text { Sum of } \\
\text { squres }\end{array}$ & $\begin{array}{c}\mathrm{F} \\
\text { value }\end{array}$ & Sig \\
\hline Gender & usage and management of self- emotions & .024 & 1 & .024 & .090 & .765 \\
\hline Hotling $=0.061$ & Identify and understand self- emotions & .378 & 1 & .378 & 1.730 & .192 \\
\hline \multirow[t]{2}{*}{$\begin{array}{l}\text { Standard } \\
\text { deviation }=0.262\end{array}$} & Dealing with the emotions of others & .054 & 1 & .054 & .277 & .600 \\
\hline & $\begin{array}{l}\text { realize the emotion through facial expressions and } \\
\text { body language }\end{array}$ & 1.079 & 1 & 1.079 & 3.304 & .072 \\
\hline Experience & usage and management of self- emotions & .662 & 3 & .221 & .813 & .490 \\
\hline Welex $=0.806$ & Identify and understand self- emotions & .636 & 3 & .212 & .970 & .411 \\
\hline \multirow[t]{2}{*}{$\begin{array}{l}\text { Standard } \\
\text { deviation }=0.080\end{array}$} & Dealing with the emotions of others & .687 & 3 & .229 & 1.184 & .320 \\
\hline & $\begin{array}{l}\text { realize the emotion through facial expressions and } \\
\text { body language }\end{array}$ & 1.895 & 3 & .632 & 1.934 & .130 \\
\hline Scientific qualification & usage and management of self- emotions & .200 & 1 & .200 & .738 & .393 \\
\hline Hotling $=0.064$ & Identify and understand self- emotions & .310 & 1 & .310 & 1.419 & .237 \\
\hline \multirow[t]{2}{*}{$\begin{array}{l}\text { Standard } \\
\text { deviations }=0.234\end{array}$} & Dealing with the emotions of others & .122 & 1 & .122 & .630 & .430 \\
\hline & $\begin{array}{l}\text { realize the emotion through facial expressions and } \\
\text { body language }\end{array}$ & .004 & 1 & .004 & .011 & .915 \\
\hline specialization & usage and management of self- emotions & .087 & 2 & .044 & .160 & .852 \\
\hline Welex $=0.851$ & Identify and understand self- emotions & .742 & 2 & .371 & 1.696 & .189 \\
\hline \multirow[t]{2}{*}{$\begin{array}{l}\text { Standard } \\
\text { deviation }=0.072\end{array}$} & Dealing with the emotions of others & .016 & 2 & .008 & .040 & .960 \\
\hline & $\begin{array}{l}\text { realize the emotion through facial expressions and } \\
\text { body language }\end{array}$ & 1.220 & 2 & .610 & 1.868 & .160 \\
\hline \multirow[t]{4}{*}{ Error } & usage and management of self- emotions & 24.719 & 91 & .272 & & \\
\hline & Identify and understand self- emotions & 19.895 & 91 & .219 & & \\
\hline & Dealing with the emotions of others & 17.610 & 91 & .194 & & \\
\hline & $\begin{array}{l}\text { realize the emotion through facial expressions and } \\
\text { body language }\end{array}$ & 29.720 & 91 & .327 & & \\
\hline \multirow[t]{4}{*}{ Total } & usage and management of self- emotions & 25.753 & 98 & & & \\
\hline & Identify and understand self- emotions & 22.404 & 98 & & & \\
\hline & Dealing with the emotions of others & 18.626 & 98 & & & \\
\hline & $\begin{array}{l}\text { realize the emotion through facial expressions and } \\
\text { body language }\end{array}$ & 33.921 & 98 & & & \\
\hline
\end{tabular}

The results shown in Table 11 indicates that the statistical values of "F" to the domains of "usage and management of self-emotions", and "to identify and understand self-emotions", and "dealing with the emotions of others", and "understand emotion through facial expressions and body language" are not statistical at the level of (0.05) and less depending on the variables of gender, experience, educational qualification, and specialization.

To find out the differences and statistical significance of the instrument as a whole; three way analysis of variance (ANOVA) was applied on the instrument as a whole, and Table 12 illustrates the results of the analysis. 
Table 12. Results of Analysis of variance test on the tool as a whole depending on the variables: (gender, years of experience, educational qualification, specialization)

\begin{tabular}{lccccc}
\hline Source of variance & Sum of squares & Df & Sum of squares & F value & Sig \\
\hline Gender & .058 & 1 & .058 & 0.351 & 0.555 \\
Experience & .464 & 3 & .155 & 0.932 & 0.428 \\
Academic qualification & .019 & 1 & .019 & 0.116 & 0.734 \\
Specialization & .054 & 2 & .027 & 0.163 & 0.850 \\
Error & 15.094 & 91 & .166 & & \\
Total & 15.657 & 98 & & & \\
\hline
\end{tabular}

It is clear from Table 12 that the statistical values of " $\mathrm{F}$ " for the variables of, gender, years of experience, academic qualifications, and specialization did not reach the level of significance at the level of (0.05) or less, thus the lack of significant differences between the faculty members in the level of emotional self-efficacy depending on the variables. This result indicates a unified culture in the same academic community; and that the nature and philosophy of the business and its values and the expected role of the faculty members are similar in different departments and colleges, and faculty members working in the light of similar organizational culture. The results are not significant in the gender and academic Qualification and it is consistent in its content with the results of Goroshit and Hen (2014) and it differs with respect to that years of teaching experience have a positive correlation with weak emotional self-efficacy.

\subsection{Recommendations}

Through the previous discussion and analysis of the study results, the following recommendations can be introduced:

- Organizing training workshops and seminars for faculty members at universities and schools, which contribute to the development of awareness of the importance of emotional self-efficacy, and its role in facilitating the building of effective relationships in the work environment.

- Conducting further studies on the subject of emotional self-efficacy through other communities, such as school and university students. And study the relationship of other variables on emotional self-efficacy such as (self-regulation, and self-assertion, emotional assimilation, and self-awareness, and vigilance of mind)

\section{References}

Arghode, V. (2013). Emotional and Social Intelligence Competence: Implications for Instructions. International Journal of Pedagogies and Learning, 8(2), 66-77. https://doi.org/10.5172/ijpl.2013.8.2.66

Bandura, A. (1977). Social learning theory. Englewood Cliffs, NJ: Prentice Hall

Bong, M., \& Skaalvik, E. M. (2003). Academic Self-Concept and Self-Efficacy: How Different Are They Really? Educational Psychology Review, 15(1), 1-40. https://doi.org/10.1023/A:1021302408382

Brígido, M., Borrachero, A. B., Bermejo, M. L., \& Mellado, V. (2013). Prospective Primary Teachers' Self-Efficacy and Emotions in Science Teaching. European Journal of Teacher Education, 36(2), 200-217. https://doi.org/10.1080/02619768.2012.686993

Choi, S., Kluemper, D., \& Sauley, K. (2013). Assessing Emotional Self-Efficacy: Evaluating Validity and Dimensionality with Cross-Cultural Samples. Applied Psychology: An International Review, 62(1), 97-132. https://doi.org/10.1111/j.1464-0597.2012.00515.x

Dagleish, T., \& Power, M. J. (1999). Handbook of cognition and emotion. New York: Wiley. https://doi.org/10.1002/0470013494

Dogan, T., Totan, T. \& Sapmaz, F. (2013). The Role of Self-Efficacy and Affect Balance on Happiness: A Path Model. European Scientific Journal, 9(20), 31-42.

Gibson, S., \& Dembo, M. H. (1984). Teacher efficacy: A construct validation. Journal of Educational Psychology, 76(4), 569-582. https://doi.org/10.1037/0022-0663.76.4.569

Goroshit, M., \& Hen, M. (2014). Does Emotional Self-Efficacy Predict Teachers Self-Efficacy and Empathy. Journal of Education and Training Studies, 2(3), 26-32. https://doi.org/10.11114/jets.v2i3.359

https://doi.org/10.1037/0022-0663.99.3.611

Maddux, J., \& Vokmann, j. (2010). Self-Efficacy. In R. Hoyle (Ed.), Handbook of Personality and 
Self-Regulation. UK: Wiley-Blackwell. A john Wiley and Sons.

Pool, L., \& Qualter, P. (2012). The Dimensional Structure of the Emotional Self-efficacy Scale. Australian Journal of Psychology, 64(1), 147-154. https://doi.org/10.1111/j.1742-9536.2011.00039.x

Pool, L., \& Qualter, P. (2013). Emotional Self-Efficacy, Graduate Employability, and Career Satisfaction: Testing The Sssociations. Australian Journal of Psychology, 65(1), 214-223. https://doi.org/10.1111/ajpy.12023

Saarni, C. (1999). The Development of Emotional Competence. New York: The Guilford Press.

Skaalvik, E. M., \& Skaalvik, S. (2007). Dimensions of teacher self-efficacy and relations with strain factors, perceived collective teacher efficacy, and teacher burnout. Journal of Educational Psychology, 99, 611-625.

Skaalvik, E. M., \& Skaalvik, S. (2014). Teacher Self-Efficacy and Perceived Autonomy: Relations with Teacher Engagement, Job Satisfaction, and Emotional Exhaustion. Psychological Reports: Employment Psychology and Marketing, 114(1), 68-77. https://doi.org/10.2466/14.02.PR0.114k14w0

Valois, R., Zullig, K., \& Hunter, A. (2013). Association between Adolescent Ideation, Suicide Attempts and Emotional Self-Efficacy. J child Fam stud, 24(1), 237-248.

Younesi, S., Tavakoli, V., Hosseini, S., \& Hashemizadeh, V. (2014). The Relation Between Emotional Self-Efficacy and Meta-Cognitive Believes With Statistical Anxiety. Indian Journal of Fundamental and Applied life Sciences, 4(2), 433-440

Zhao, X., You, X., Sni, C., Yang, X., Chu, K., \& Peng, Z. (2013). Factor Analysis of the Regulatory Emotional Self-Efficacy Scale of Chinese College Students. Social Behavior and Personality, 41(5), 751-760. https://doi.org/10.2224/sbp.2013.41.5.751

Zulkosky, K. (2009). Self-efficacy: A Concept Analysis. Nursing Forum, 44(2), 93-102. https://doi.org/10.1111/j.1744-6198.2009.00132.x

\section{Copyrights}

Copyright for this article is retained by the author(s), with first publication rights granted to the journal.

This is an open-access article distributed under the terms and conditions of the Creative Commons Attribution license (http://creativecommons.org/licenses/by/4.0/). 